\title{
USABILITY ASSESSMENT OF AGROTOURISM FARM WEBSITES IN POLAND
}

\author{
Karol KRÓL ${ }^{1}$, Dariusz ZDONEK ${ }^{2 *}$ \\ ${ }^{1}$ University of Agriculture in Kraków, Faculty of Environmental Engineering and Land Surveying; \\ k.krol@onet.com.pl, ORCID: 0000-0003-0534-8471 \\ ${ }^{2}$ Silesian University of Technology in Gliwice, Faculty of Organisation and Management; \\ dariusz.zdonek@polsl.pl, ORCID: 0000-0002-6190-9643 \\ * Correspondence author
}

Purpose: Interactivity and simplicity of navigation make users browse a website, and its usefulness is the main factor which influences the intention of using it to buy a product or service. The aim of the paper was to identify the most frequent project errors that negatively impact the usability of websites of agortourism farms.

Design/methodology/approach: The surveys were carried out by the audit method in a set of websites which were grouped according to accepted categories. The audit was based on a heuristic analysis using a control list.

Findings: A number of usability problems have been identified in the set of examined websites; however, the most important were the lack of explicit updates or the presentation of outdated information, as well as the dysfunction of forms - contact and inquiry. Zero-category sites are unusable. They are characterised, among others, by no visible updates (or presentation of outdated information), archaic technique of execution, often based on so-called "Frames" (iframes) or tables, as well as imperfect, archaic graphic design.

Originality/value: The usefulness of a website (reflected in the design details) goes into the background when it only serves an information and contact function and does not provide advanced functionalities, such as, for example, an accommodation booking form. In the case of agrotourism farms, the most important elements are the thematic graphic design and exhaustive content.

Keywords: promotion of agrotourism, Internet marketing, usability audit, usable quality of websites, heuristic analysis.

\section{Introduction}

Agrotourism is a form of rest on a farm with a preserved agricultural function, which allows one to learn about the specificity of living and working in the countryside (Balińska, 2014, p. 251). Popularity of this kind of holiday in Poland is growing, both among accommodation 
providers and vacationers (Czarniewski, 2011, p. 69; Król, Halva, 2017, p. 50). Agrotourism has a significant impact on the sustainable development of rural areas, contributing to the economic growth in its area, including the creation of new jobs (Brelik, 2010, p. 153; Sikora, Wartecka-Ważyńska, 2012, p. 9). It is one of the ways of economic and social activation of the rural population, as it supports the sale of agricultural products and handicrafts and also affects the perception of rural areas and agriculture (Tew, Barbieri, 2012, p. 215). Tourism in rural areas is sometimes treated as a panacea for numerous rural problems, but in some regions, it develops very spontaneously, taking on commercialised forms, which also causes negative phenomena, including changes in the natural environment and transformation of the settlement network structure, as well as social changes, mainly in the sphere of the culture and value system (Kachniewska, 2011, p. 53).

The success of agrotourism activities implemented in the competitive environment depends to a large extent on the activities that will allow the farms to obtain a satisfactory number of customers (Wilk, Keck-Wilk, 2013, p. 243). These activities can be broadly divided into internal (increasing the attractiveness of the offer) and external, in particular in the broadly defined promotion. Providing information on the tourist offer is an important factor stimulating the development of tourism in rural areas (Szpara, Gwóźdź, 2011, p. 221).

Many owners of agrotourism farms are looking for a way to distinguish their offer from many others and reach out to a larger number of clients. In order to achieve this, they most often use the potential of the Internet (Król, Bedla, 2014, p. 22; Krzyżanowska, 2014, p. 41; Hashim, Isse, 2019, p. 267; Martínez-Sala et al., 2020). For small entrepreneurs in this industry, direct access to potential clients eliminates or minimises the costs of brokering of large tourist organisations and facilitates the creation of local networks of service providers (Argasiński, 2014, p. 157).

The effectiveness of agrotourism promotion on the Internet is sometimes limited by the low level of marketing and IT competences of the hosts, as well as lack of trust in online tools and uncertainty about own skills in this field (Tomczak-Woźniak, 2013, p. 583; Kachniewska, 2014, p. 86). Global technological changes (Król, 2016, p. 84), dispersion of information on agrotourism facilities (Balińska, 2014, p. 251) and the fact that the technique of making a large number of agrotourism farm sites and the quality of content they present are of significant meaning; however, they leave a lot to be desired (Król, 2019, p. 461).

Interactivity and ease of navigation incline users to browse a site, and its usability is the main factor that affects the intention to use it in the shopping process (San Martín, Herrero, 2012, p. 341). The aim of the work is to assess the usefulness of websites of agrotourism farms. The research assumes the hypothesis that design errors reduce the usability of websites, and specific usability problems may be characteristic of specific design techniques. 


\section{Usability of websites}

Three aspects of the usable quality of the system are most important for the user (computer): (1) functionality, understood as the choice of function, adequately to the purpose of the system, as well as the user's needs and goals; (2) ergonomics, meaning the possibility of achieving the assumed goals with as little effort as possible; and (3) usability, which is the resultant of achieving the user's goals, the effort incurred and the level of satisfaction with use (Sikorski, 2012, p. 80).

Websites have a specific function, e.g. information, contact, booking and payment, through shared functionalities that are more or less useful (Król, 2015, p. 343). The quality of the site, effectiveness, efficiency and comfort of its browsing are determined by the technique of its implementation, the uniqueness and timeliness of the content it presents, as well as the form of their presentation, often generally referred to as the usable quality of the website.

The usefulness of a website is related to the concept of "user experience" (UX), which describes the emotional experience and feelings of the user appearing in contact with a given product, system (computer) or service. User experience is an increasingly common term used in relation to the emotional aspect of the quality of interactive products. It can be a distinctive feature of a product or service against the background of competitive solutions and a promise of their high quality (Sikorski, 2012, p. 85). UX combines graphic design - "UI design" (user interface design) and designing communication processes and testing them. It is a broader concept than usability, because it also covers aspects of a user's interaction with the organisation, its services and products, as well as the thoughts, observations and emotions connected with it (user experience assessment, UXA). In turn, user-oriented design focuses on positive experiences resulting from the comfort of using the website, which should also be visually appealing (Sharma, Sharma, 2017, p. 239).

The ergonomics of the user interface, the usability of the website and the quality of interaction are often seen as a promise of a high-quality offer that the customer is considering using. For this reason, e-business systems pay great attention to convenience of service. The lack of this feature may lead the customer to take advantage of a competitive offer (Sikorski, 2012, p. 78).

Usability is a subjective impression of the user, often depending on the context and variable in time, shaped during or after interaction with the website. Objective evaluation of usability is therefore relatively difficult.

There are many factors that affect the user experience of using a website. These include, among others: (1) navigation ergonomics (navigability), i.e. the ability to quickly access information; (2) functionality (website functionality), which defines the scope of functions of a given website; (3) consistency (website consistency), i.e. repeatability, integrity of the website structure; (4) simplicity, meaning moderation, lack of unnecessary advertisements, ornaments and components; (5) readability, resulting from the perceptual accessibility of the text and its formatting; as well as (6) user support (supportability) (Garrett, 2011). Website usability can 
be examined using usability evaluation and expert evaluation. The heuristic evaluation is helpful (Masip, Granollers, Oliva, 2011, p. 429), and the so-called usability checklist containing the project guidelines, i.e. a list of "good practices" (Nielsen, Mack, 1994). The checklist contains queries about the critical attributes of the site and the requirements that it should meet. In addition, the heuristic analysis facilitates a so-called "cognitive walkthrough", which involves testing the website by performing actions according to a test scenario.

The usability evaluation is usually performed in the form of a usability audit. It allows checking if the website meets design standards. The audit usually consists in assessing website usefulness by an expert, based on their knowledge and experience. Design and usability specialists often develop their own evaluation criteria based on experience and professional practice. In addition, in the search for proven solutions, the usability of the tested site is compared to the usefulness of competing websites (competitor review) or sites presenting content from another industry (opportunity review). The main task of the audit is to indicate crucial points of the website which may have a negative impact on its usability and require optimisation.

\section{Research technique}

The research was carried out on a set of 30 websites, the addresses of which were acquired on 1 June 2017 from an accommodation offer search engine, made available by the industry portal 'agroturystyka.pl'. This portal is maintained by the Polish Federation of Rural Tourism "Hospitable Farms". Each of the sites was subjected to a usability audit, which was performed using the heuristic analysis method utilising a checklist provided by D. Travis (2014). The analysis was made possible by observations made during the simulation of a user's visit to the website, along with an attempt to perform selected tasks - sending an inquiry and submitting a booking via an online form (if available) - paying special attention to usability problems and system (programming) errors.

The basic version of the checklist was adapted to the nature of the tested websites. Its original version included 247 questions in the area, among others, of usability of the home page, navigation, layout, ergonomics, graphic design, forms, as well as news and quality of content. On the other hand, in the assessment of agrotourism farm websites, one omitted questions strictly related to the usability of the access authorisation system and user account creation (registration and logging into the system), content search system (none of the sites provided content search engines), as well as the purchase process (websites of agrotourism farms rarely mediate in electronic transactions). Finally, 162 control questions were used, according to which each site was rated. When verifying attributes from the checklist, one point $(-1)$ was subtracted if the site did not meet the given requirement, or the site was granted $(+1)$ 
if the condition was met. If the condition was fulfilled to a certain degree, zero points were awarded (0). If the attribute from the checklist did not apply to the evaluated website, it was not evaluated. In a simplified way, this means that the smaller number of points checked was synonymous with less functionality of the website.

The websites of agrotourism farms are mainly differentiated in terms of execution technique. The menu structure and subject matter of the published content are usually similar. The research assumes the hypothesis that specific usability problems may be characteristic of a particular level of applied design techniques. Hence, the surveyed sites were selected randomly, though according to categories, which were created based on selected engineering criteria describing the main design attributes of websites (Table 1) - the first (dynamic, responsive RWD, AWD - responsive, adaptive web design, made according to project standards HTML5), medium (dynamic sites, no responsiveness, made in the XHTML standard, DHTML - Dynamic HyperText Markup Language) and zero (archaic, static sites, made in one of the HTML 4.0 or older specifications, usually managed through an FTP client). The audit involved 10 sites from each category.

\section{Table 1.}

Criteria for classification and selection of websites for usability tests

\begin{tabular}{|c|c|c|c|}
\hline \multirow{2}{*}{ Attribute of execution technique } & \multicolumn{3}{|c|}{ Website category } \\
\cline { 2 - 4 } & first & medium & zero \\
\hline HTML specification, DTD headline & HTML5 & XHTML & Static HTML \\
\hline Content presentation technique & RWD, AWD & DHTML & FTP \\
\hline Content management & CMS & CMS or FTP & In the free domain \\
\hline Website address & $\begin{array}{c}\text { In the national } \\
\text { domain ccTLD }\end{array}$ & $\begin{array}{c}\text { In the national domain } \\
\text { ccTLD or subdomain }\end{array}$ & \\
\hline
\end{tabular}

RWD - Responsive Web Design (responsiveness, compliance of the site with mobile devices), AWD - Adaptive Web Design (technique of implementing responsiveness), DHTML - Dynamic HyperText Markup Language (dynamic HTML), CMS - Content Management System, FTP - File Transfer Protocol (in the sense of managing content by overwriting files on a data server).

Source: own elaboration.

Considering that the variables adopted for the analysis were of a different character, in the unitarisation process, the formula (1) for the stimulant and the formula (2) for the destimulant were used. Next, the values of the aggregate variable were determined, which allowed us to describe each site with a synthetic utility indicator (Król, 2019, p. 461).

$x_{i j}^{\prime}=\frac{x_{i j}-\min _{i}\left\{x_{i j}\right\}}{\max _{i}\left\{x_{i j}\right\}-\min _{i}\left\{x_{i j}\right\}}$

$x_{i j}^{\prime}=\frac{\max _{i}\left\{x_{i j}\right\}-x_{i j}}{\max _{i}\left\{x_{i j}\right\}-\min _{i}\left\{x_{i j}\right\}}$

$\mathrm{i}=1,2, \ldots, \mathrm{n} ; \mathrm{j}=1,2, \ldots, \mathrm{m}$

zij - standardised diagnostic variable,

xij - non standardized diagnostic variable,

$\operatorname{mini}\{x i j\}$ - the minimum value of the non-standardised diagnostic variable,

$\operatorname{maxi}\{x i j\}$ - the maximum value of the non-standardised diagnostic variable. 
In the last stage, the value of the synthetic, "cumulative utility index" (SWU) for each set of sites was determined.

\section{Research results}

There was no significant difference in the number of usability conditions met between the first and medium category sites. At this point, it should be specified that the tests were carried out in terms of the usability of websites on computers in the so-called desktop mode. Given that the websites from the first category were responsive (the layout of the website automatically adapts to the screen of the device on which it is viewed), unlike those from the medium category, tests carried out on mobile devices could show greater usability differences. However, there was a large difference in usability between first- and middle-level sites, as well as zero-site sites. In this set, a total of 268 usability errors were recorded, i.e. 84 more than for the first- and middle-category sites combined (Table 2). The value of the cumulative, synthetic usability index in this set was 12.5 points. This is twice less compared to sites in the first category. In addition, all zero-category sites obtained a low value of the synthetic usability index (Table 3), receiving an average of 27.5 points out of the 162 possible to obtain. At the top of the ranking, there were 4 sites of the first category (average usability rating at the level of 87 points), and 2 websites from the medium category (average usability rating at a level of 82 points). In most cases, these sites were characterised by a simple structure, with content presented on the home page or in the range of "one click" and single-level, the so-called "shallow" menu.

Table 2.

Audit statistics according to Travis' modified checklist (2014) for all tested sites combined

\begin{tabular}{|c|c|c|c|c|}
\hline $\begin{array}{c}\text { Website } \\
\text { category }\end{array}$ & $\begin{array}{c}\text { Number of } \\
\text { responses }\end{array}$ & $\begin{array}{c}\text { Number of fulfilled } \\
\text { usability conditions }\end{array}$ & $\begin{array}{c}\text { Number of usability } \\
\text { problems }\end{array}$ & $\begin{array}{c}\text { Value of the cumulative } \\
\text { utility indicator }\end{array}$ \\
\hline First & 1,095 & 870 & 85 & 24.7 \\
\hline Medium & 1,084 & 820 & 99 & 23.6 \\
\hline Zero & 1,004 & 277 & 268 & 12.5 \\
\hline
\end{tabular}

Source: own elaboration.

Table 3.

Number of sites in each SWU interval, by category

\begin{tabular}{|c|c|c|c|}
\hline \multirow{2}{*}{ Website category } & \multicolumn{2}{|c|}{ Ranges of the value of the synthetic utility indicator SWU } \\
\cline { 2 - 4 } & Low (0.1-1.99) & Medium (2.0-2.39) & High (2.4-3.0) \\
\hline First & 0 & 4 & 6 \\
\hline Second & 1 & 5 & 0 \\
\hline Zero & 10 & 0 & 10 \\
\hline Total & 11 & 9 & 4 \\
\hline
\end{tabular}

Source: own elaboration. 
On 12 sites, "sending message" forms (5 of which are on the first category websites) were recorded, and so they should be taken into account, although they were repeatedly titled as "reservation forms". In fact, these were relatively simple scripts that sent an e-mail message with specific content.

Although forms can be a critical component of agrotourism farm websites, the efficiency of 2 forms out of 12 recorded was questionable (no feedback in the form of a message to send or not send a message), and 5 forms did not work at all.

\section{Conclusions}

Zero category sites are unusable. They are characterised, among others, by no visible updates (or presentation of outdated information), archaic technique of execution, often based on so-called "Frames" (iframes) or tables, as well as imperfect, archaic graphic design. This does not inspire a user's trust and questions the credibility of the offer. This is clearly demonstrated by usability studies. Only one site within the zero category obtained a positive result in the assessment of attributes from the set of "trust and credibility" (3 points out of a possible 13), but the others scored zero or negative number.

Zero category sites are quickly loaded in the web browser window. However, this is not due to intended project activities, but results from their simple construction, the small number of graphic files used and the total lack of functionality (these websites usually take the form of static business cards or individual hypertext documents, so-called "information cards"). In addition, these sites are often placed in the free domain and on free servers (see Król, Zdonek, 2017, p. 157).

When browsing archaically made websites, one can follow the changes that have taken place, not only in terms of graphic patterns and design standards, e.g. from a gallery created from scans of analogue photographs to interactive spherical panoramas (see Król, 2018, p. 274), but also how the standard of tourist services offered by farms have changed and how they have been modernised.

The selected usability gaps are of real significance for users browsing the site in search of details of the accommodation offer, in particular those related to the efficiency of contact forms. The importance of usability increases when the website fulfils advanced sales functions, including booking and paying. In addition, a poor navigation system, lack of consistency in the use of print or incorrect hierarchy of information placed on a bulleted list are not as important to the average user as the specific offer description, price list and contact details. 
A number of usability problems have been identified in the set of examined websites; however, the most important were the lack of explicit updates or the presentation of outdated information, as well as the dysfunction of forms - contact and inquiry. The selected sites gave an impression of being "abandoned". Even a small amount of activity consisting of a periodical update of the price list with the date of the current season confirms that there is a specific person behind the display and the current offer is up to date.

\section{Summary}

The tests carried out on a relatively small sample showed the main problems of utility of agrotourism farm sites, and the results of research are an indication that owners of agrotourism farms may need technical assistance in servicing their websites, as well as Internet marketing tips. This is a clue for entities offering educational services, including universities that teach in fields related to tourism, agricultural advisory centres and agritourist associations.

It is difficult to talk about the usefulness of the websites of agrotourism farms in general. The usability of a specific site or site collection with similar parameters (from a given quality group) can be evaluated. The usefulness of sites from the first and the middle category was similar. Basically, they differed in graphic design. This in turn was dependent upon the used design techniques.

Many zero-class sites cannot be improved, optimised or refined. Their usability and functionality are negligible or none, and they do not fulfil their function. In addition, this is compounded by intrusive ads, the presentation of which hinders the free browsing of content, which is associated with the use of a free hosting package. Each of these sites needs to be archived and created again in accordance with applicable standards.

The usefulness of the website (reflected in the design details) goes into the background when it only serves an information and contact function and does not provide advanced functionalities, such as, for example, an accommodation booking form. In the case of agrotourism farms, the most important elements are the thematic graphic design and exhaustive content including, above all, the description of the offer, price list and contact details, all supplemented with photographs or multimedia materials. In addition, the site should be visibly updated and free from programming errors. 


\section{References}

1. Argasiński, W. (2014). Korzyści z partnerstwa w turystyce (na przykładzie programu marketingowego Karta Tatrzańska). Handel Wewnętrzny, 6(353).

2. Balińska, A. (2014). Determinanty popytu mieszkańców Warszawy na usługi agroturystyczne. Zeszyty Naukowe Uniwersytetu Szczecińskiego, Ekonomiczne Problemy Turystyki, 1(25).

3. Brelik, A. (2010). Zrównoważony rozwój społeczno-gospodarczy a rozwój agroturystyki. Roczniki Ekonomiczne Kujawsko-Pomorskiej Szkoły Wyższej w Bydgoszczy, 3.

4. Czarniewski, S. (2011). Przesłanki rozwoju gospodarstw agroturystycznych. Ekonomika i Organizacja Przedsiębiorstwa, 2.

5. Garrett, J.J. (2011). The Elements of User Experience: User-Centered Design for the Web and Beyond. New Riders.

6. Hashim, N.L., Isse, A.J. (2019). Usability Evaluation Metrics of Tourism Mobile Applications. Journal of Software Engineering and Applications, 12(7).

7. Kachniewska, M. (2011). Funkcja turystyczna jako determinanta jakości życia na wsi. Folia Pomer. Univ. Technol. Stetin., Oeconomica, 288(64).

8. Kachniewska, M. (2014). Wpływ digitalizacji kanałów dystrybucji na strukturę rynku usług pośrednictwa turystycznego. E-mentor, 1(53).

9. Król, K. (2015). Funkcjonalność oraz funkcje witryn internetowych gospodarstw agroturystycznych. Ekonomia i Zarzadzanie, 7(1).

10. Król, K. (2016). Globalne zmiany technologiczne i ich wpływ na promocję agroturystyki w internecie. Roczniki Naukowe Ekonomii Rolnictwa i Rozwoju Obszarów Wiejskich, 103(3).

11. Król, K. (2018). Wirtualizacja oferty agroturystycznej. Handel Wewnętrzny, 1(372).

12. Król, K., Bedla, D. (2014). Ocena witryn internetowych gospodarstw agroturystycznych. Marketing i Rynek, 11 .

13. Król, K., Halva, J. (2017). Measuring efficiency of websites of agrotouristic farms from Poland and Slovakia. Economic and Regional Studies, 10(2).

14. Król, K., Zdonek, D. (2017). Charakterystyka rynku usług hostingowych w Polsce. Zeszyty Naukowe Politechniki Śląskiej. Organizacja i Zarządzanie, 102.

15. Król, K. (2019). Forgotten agritourism: abandoned websites in the promotion of rural tourism in Poland. Journal of Hospitality and Tourism Technology, 10(3).

16. Krzyżanowska, K. (2014). Skuteczność działań informacyjno-promocyjnych w turystyce wiejskiej. Zeszyty Naukowe Uniwersytetu Szczecińskiego, Ekonomiczne Problemy Turystyki, 3(27).

17. Kukuła, K., Bogocz, D. (2014). Zero Unitarization Method and Its Application in Ranking Research in Agriculture. Economic and Regional Studies, 7(3). 
18. Martínez-Sala, A.M., Monserrat-Gauchi, J., Alemany-Martínez, D. (2020). User Usable Experience: A three-dimensional approach on usability in tourism websites and a model for its evaluation. Tourism Management Perspectives, 33, 100579.

19. Masip, L., Granollers, T., Oliva, M. (2011). A heuristic evaluation experiment to validate the new set of usability heuristics. Information Technology: New Generations (ITNG), 2011 Eighth International Conference. IEEE.

20. Nielsen, J., Mack, R.L. (1994). Usability Inspection Methods. New York: John Wiley \& Sons.

21. San Martín, H., Herrero, Á. (2012). Influence of the user's psychological factors on the online purchase intention in rural tourism: Integrating innovativeness to the UTAUT framework. Tourism Management, 33, 2.

22. Sharma, A., Sharma, A. (2017). Managing User Experience (UX) Design Practice: Approaches and Considerations. International Conference on Research into Design. Singapore: Springer.

23. Sikora, J., Wartecka-Ważyńska, A. (2012). Wybrane teoretyczne aspekty agroturystyki. Zeszyty Naukowe Uniwersytetu Szczecińskiego, Ekonomiczne Problemy Turystyki, 2(18).

24. Sikorski, M. (2012). Ustugi on-line: jakość, interakcje, satysfakcja klienta. Warszawa: Wydawnictwo PJWSTK.

25. Szpara, K., Gwózdz, M. (2011). Zastosowanie nowoczesnych technologii w promocji turystyki kulinarnej na przykładzie terenów wiejskich województwa podkarpackiego. Folia Pomer. Univ. Technol. Stetin., Oeconomica, 286(62).

26. Tew, Ch., Barbieri, C. (2012). The perceived benefits of agritourism: The provider's perspective. Tourism Management, 33, 1.

27. Tomczak-Woźniak, E. (2013). Polskie rolnictwo wobec wyzwań e-gospodarki. Zeszyty Naukowe Uniwersytetu Szczecińskiego. Ekonomiczne Problemy Ustug, 105(2).

28. Travis, D. (2014). 247 web usability guidelines. Retrieved from https://goo.gl/PpCm, 06.08.2017.

29. Wilk, I., Keck-Wilk, M. (2013). Oczekiwania turystów dotyczące oferty gospodarstw agroturystycznych. Journal of Agribusiness and Rural Development, 2(28). 